\title{
Law Enforcement of Fisheries Crime in North Maluku Province through Transcendental Paradigm
}

\author{
Muhammad Amin Hanafi \\ Universitas Muhammadiyah Ternate \\ aminhanafi76@mail.com
}

\author{
Absori \\ Universitas Muhammadiyah Surakarta \\ absori@ums.ac.id \\ Khudzaifah Dimyati \\ Universitas Muhammadiyah Surakarta \\ kd255@ums.ac.id \\ Ajid Abdul Syawal \\ Khairun University of Ternate \\ syawalabdulajid23@gmail.com \\ Arief Budiono \\ Universitas Muhammadiyah Ponorogo \\ areevahims@gmail.com
}

DOI: $10.23917 / j t l . v 2 i 1.11368$

Submission
Track:
Received:
03 June 2020
Final Revision:
04 July 2020
Available online:
31 July 2020
Corresponding
Author:
Muhammad Amin Hanafi
aminhanafi76@mail.com
Absori
absori@ums.ac.id

\begin{abstract}
Objective: This article aims to discuss the enforcement of customary law in North Maluku, the deliberation value in the BMA Sultanate of Ternate, and the implementation of customary criminal sanctions by the Badan Musyawarah Adat.
\end{abstract}

Methodology: The methodology used in this study was legal research conducted in a non-doctrinal qualitative approach. In this study, the law is not only conceptualized as all the principles and rules that regulate human life in society but also includes institutions and processes that actualize the validity of these rules in society.

Findings: Law enforcement of fisheries crimes is based on the provisions of Indonesian Law No. 45 of 2009 concerning Fisheries. Criminal provisions are regulated by Articles 84 to 104. One of them is about sinking the ship used to commit fishing crimes. Sanctions given to the fish theft (illegal fishing) perpetrators in territorial waters that have been determined by the local customary head are 1) warning; (2) monetary charges according to the agreement of the local customary community; and (3) boat (pajeko in Ternate) or motorboat 


\begin{tabular}{l}
\hline Khudzaifah Dimyati \\
kd255@ums.ac.id \\
Ajid Abdul Syawal \\
syawalabdulajid23@gmail.com \\
Arief Budiono \\
areevahims@gmail.com
\end{tabular}

seized by the sultanate to be used by the community through profit sharing.

Utility: Customary Institute of Ternate Sultanate in 2018 has decided on three cases in the Kao bay area concerning fish catching. Besides the traditional law enforcement that is implemented by the Sultanate, North Maluku recognizes Sasi Customs (Adat Sasi), which is regulation of tradition that limits people for catching fish or taking other sources in a certain type and particular period. Thus, the ecological balance is still maintained.

Novelty/Originality: The concept of transcendental law enforcement is substantially in line with the values in the Segulaha tradition that has been applied for a long time in North Maluku. In Segulaha customary law, there is a traditional element in a person who has the same soul with transcendental values by positioning revelation as the source of the law.

Keywords: Law Enforcement, Fisheries Crimes, Transcendental Approach

\section{INTRODUCTION}

Indonesia has $6,315,222 \mathrm{~km}^{2}$ of the territorial waters with an archipelago coastline reaching $99,093 \mathrm{~km}$. The number of Indonesian islands that have been standardized by the National Team on Standardization of Indonesian Geography (Rupabumi) is 13,466 islands. Besides, the potency of Indonesian fisheries reaches the US \$31,935,651,400/year. Hence, the existence of abundant natural resources in Indonesia makes the existence and position of Indonesia are strongly strategic. This fact is God's gift for the capital of power, opportunities, as well as a threat to the sustainability of this Nation, especially from the practice of fish plundering. ${ }^{1}$ The absence of abundant fish in the oceans of other countries becomes the reason why numerous fishers from abroad come to Indonesia. Overfishing in Indonesia is also caused by a weak regulatory system. The extent of Indonesia's sea is not proportionate with the number of Human Resources tasked with monitoring, managing, and protecting the sea. This condition is certainly very alarming considering that Indonesia has been known as a maritime country. ${ }^{2}$

\footnotetext{
${ }^{1}$ Kardono, Priyadi (Ed). (2015). Paradigma Geomaritim; Strategi Mewujudkan Indonesia Sebagai Poros Maritim Dunia dalam Perspektif Geografi. Diterbitkan oleh Badan Informasi Geospasial (BIG) didukung oleh Ikatan Geograf indonesia (IGI)

${ }^{2}$ Lapian, AB. (2015). Orang Laut-Bajak Laut-Raja Laut-Sejarah Kawasan Laut Sulawesi Abad XIX. Depok: Komunitas Bambu.
} 
Crime in the Fisheries field basically has a difference with other criminal acts. This difference is in Locus Delicti, which is in the water area that has its classification. Meanwhile, the sea area of a country can be classified into two parts. The first part is sea or waters that become the territory of a country, including inland waters, archipelagic waters, and territorial sea in which the coastal/island country has sovereignty. ${ }^{3}$ Meanwhile, those that are not the territory of a country are including Contiguous Zone, Exclusive Economic Zone (EEZ), Continental shelf, high seas, and deep seabed/area. ${ }^{4}$

Legally, illegal fishing and several forms of acts that are mentioned previously can be classified as fisheries criminal acts. It is stated in Chapter XV of the Criminal Provisions Law No. 31 of 2004 concerning Fisheries with criminal qualifications in several Articles and violations in several other Articles. Nevertheless, if it is assessed from the level and the number of State losses that are experienced each year, then as an illegal act, this crime can be classified as an economic crime. ${ }^{5}$

As an economic crime, it is very alarming, especially with the lack of supervision and law enforcement. Research conducted by Armain Naim showed that among eighteen fishery supervisors or $100 \%$ of respondents said that prosecutors' demands were too low and were not comparable to the State losses due to illegal fishing. Therefore, the process of law enforcement on illegal fishing is still not optimal although it is supported by the fishermen who are ready to report if there are irregularities. The readiness of law enforcement officers must respond fish theft with these various modes. High potency of fisheries, huge sea, and diverse other biological wealth will be very wasted if the theft occurs. The police become the Avant-Garde in handling fish theft that occurs in the area. ${ }^{6}$

The clarity of authority to conduct an investigation is highly dependent on the Locus Delicti in part of the area where the crime occurs. For example, an institution authorizes to investigate if fishery crime happens in a territorial sea area. Likewise, an institution has the authority to investigate if the offense occurs in the Exclusive Economic Zone. On the other hand, structuring authority for institutions must be conducted by understanding that law

\footnotetext{
${ }^{3}$ Undang-Undang Nomor 6 Tahun 1996 tentang Perairan Indonesia

${ }^{4}$ Buntoro, Kresno. (2013). Kegiatan Militer Di Zee Dan Pelaksanaan Hot Pursuitdi Indonesia. Jurnal Opinio Juris, Vol. 12.

${ }^{5}$ Lewerissa, Yanti Amelia. (2010). Praktek Illegal Fishing di Perairan Maluku sebagai Bentuk Kejahatan Ekonomi. Jurnal Sasi, Vol.16. No.3.

${ }^{6}$ Naim, Armain. (2010). Pengawasan Sumberdaya Perikanan dalam Penanganan Illegal Fishing di Perairan Provinsi Maluku Utara, Jurnal Ilmiah agribisnis dan Perikanan (agrikan UMMU-Ternate) Volume 3 Edisi 2.
} 
enforcement is a systemic activity. While using the framework that law enforcement is a systemic activity, the structure must be conducted comprehensively. Law, institutional, and cultural enforcement must be organized thoroughly. From the result of this investigation, it is expected that later on, it will be able to uncover the illegal fishing in North Maluku, Indonesia, which is very harmful.

\section{Law enforcement for the fish theft crime in North Maluku}

Law enforcement is a series of justice process through law enforcement officials who work based on the authority aiming at having justice based on noble values. Law enforcement can also be an effort of legal justice values that are emitted to all those who want justice.

According to the interview result that was conducted by researchers in the field with the villagers in Posi-Posi Rao Village, Morotai Island District, there was arrest performed by the navy on foreign fishing ships. It began with a fisherman report in which the fishermen had repeatedly passed foreign fishing ships when the ship did illegal fishing in Indonesian territory, especially on Morotai Island, North Maluku Province, Indonesia.

The report from Om Ade was confirmed by the Antarctic Marine Natural Resources Conservation Commission that RFMO for the Antarctic region recorded 3 (three) Transnational companies conducting Illegal Fishing in Indonesian territory. The 3 (three) Transnational companies were Hai Fa, Pusaka Punjana, and FV Viking. Several ships' crews from the three companies were from China, even the ship's crews of Pusaka Punjana were from Panama.

Table 1. Data Sources from North Maluku Navy

\begin{tabular}{|c|c|c|c|}
\hline $\begin{array}{l}\text { Ship's Name and } \\
\text { Deadweight } \\
\text { Tonnage }\end{array}$ & $\begin{array}{l}\text { Ship Captain's } \\
\text { Name and crews }\end{array}$ & $\begin{array}{l}\text { Location } r \text { of } \\
\text { arresting illegal } \\
\text { fishing ship by } \\
\text { Navy }\end{array}$ & Note \\
\hline $\begin{array}{l}\text { KM Hai Fa } \\
\text { Ship's weight in } 125 \\
\text { GT }\end{array}$ & $\begin{array}{l}\text { Lo Ming as a Ship } \\
\text { Captain. } \\
\text { Ngixu. Ah Nio, Lou, } \\
\text { and Wuxiang as } \\
\text { main ship crews }\end{array}$ & $\begin{array}{l}\text { North of Morotai } \\
\text { Island. }\end{array}$ & $\begin{array}{l}\text { The three ships were } \\
\text { from China. The } \\
\text { ships were sunk by } \\
\text { exploding. }\end{array}$ \\
\hline
\end{tabular}




\begin{tabular}{|c|c|c|}
\hline & $\begin{array}{ll}\text { (Anak } & \text { Buah } \\
\text { Kapal/ABK). } & \end{array}$ & $\begin{array}{l}\text { Coordinate point } 11^{\circ} \\
\text { Miles of the Morotai } \\
\text { islands } \\
\text { Monday. 05:30 WIT }\end{array}$ \\
\hline $\begin{array}{l}\text { Pusaka Pujana Motor } \\
\text { Ship } \\
\text { Ship's weight in } 135 \\
\text { GT }\end{array}$ & $\begin{array}{l}\text { Max Karl as a ship } \\
\text { captain. } \\
\text { Most of the ship } \\
\text { crews were Panama } \\
\text { Nationality. }\end{array}$ & $\begin{array}{l}\text { Behind area of Posi- } \\
\text { Posi Rao Island, Sub- } \\
\text { district of Morotai } \\
\text { Island. } \\
\text { Coordinate point } 9^{\circ} \\
\text { Nautical Miles. } \\
\text { Morotai Island. } \\
\text { Thursday. } \\
\text { WIT }\end{array}$ \\
\hline $\begin{array}{l}\text { FV Viking Motor } \\
\text { Ship } \\
\text { Ship's Weight in } 95 \\
\text { GT }\end{array}$ & $\begin{array}{l}\text { Tan Xu as a ship } \\
\text { captain. } \\
\text { Main ship crews } \\
\text { (Anak Buah } \\
\text { Kapal/ABK): Wang } \\
\text { Mei, Jhiet Wei, Fo } \\
\text { Xan, Wei, and A } \\
\text { Ming. }\end{array}$ & $\begin{array}{l}\text { Around Halmahera } \\
\text { Sea, Widi Island, } \\
\text { South Halmahera } \\
\text { District. } \\
\text { Coordinate point } 7^{\circ} \\
\text { Ocean miles } \\
\text { Sunday. 13:35 WIT }\end{array}$ \\
\hline
\end{tabular}

However, according to Armain Naim, concerning the result of surveillance operation in 2012-2016 in North Maluku waters, the number of inspected fishing ships was 282 Indonesian fishing ships and five foreign fishing ships. It is seen in the table below:

Table 2. Result of surveillance operation in 2012-2016 in North Maluku waters 


\begin{tabular}{|c|c|c|c|c|c|c|c|c|}
\hline \multirow[t]{3}{*}{ Year } & \multirow{2}{*}{\multicolumn{2}{|c|}{$\begin{array}{c}\text { Being } \\
\text { Investigated }\end{array}$}} & \multirow{2}{*}{\multicolumn{4}{|c|}{ Arrested }} & \multirow{2}{*}{\multicolumn{2}{|c|}{$\begin{array}{c}\text { Being } \\
\text { Repatriated }\end{array}$}} \\
\hline & & & & & & & & \\
\hline & KII & KIA & KII & KIA & KII & KIA & KII & KIA \\
\hline 2012 & 63 & - & 11 & - & - & - & 52 & - \\
\hline 2013 & 66 & - & 4 & - & - & - & 62 & - \\
\hline 2014 & 49 & 3 & 3 & 1 & - & - & 46 & - \\
\hline 2015 & 45 & - & 10 & - & - & - & 35 & - \\
\hline 2016 & 59 & 4 & 25 & 4 & - & 4 & 34 & - \\
\hline Total & 282 & 7 & 53 & 5 & - & 4 & 229 & - \\
\hline
\end{tabular}

Note: KII = kapal ikan Indonesia (Indonesian fishing ships), KIA= kapal ikan asing (foreign fishing ships)

Source: KKP-Satuan SDKP Ternate, DKP of North Maluku Province

From the number of inspected fishing ships, 229 Indonesian fishing ships were repatriated while 53 ships were in processed status (ad-hoc). The most common violation that is done by Indonesian fishing ships was the violation of fishing areas. Indonesian fishing ships often conduct fishing activities in fishing locations or areas that are not following the permits listed in the Fish Catching Permit Letter (SIPI) of Indonesia. After passing the stages of the process, Indonesian fishermen will be given sanctions in the form of monetary charges. The legal basis used concerning the claim is in Article 7 Paragraph 2, Jo article 100, Indonesian Law No. 45 of 2009.

However, condition differed regarding foreign fishing ships, the number of the ad-hoc status ship was four units in 2016. Each type of fishing ship consists of 1 unit of purse seine size 125 GT, 1 unit of carrier ship size 88 GT, 1 unit of hand line ship size 30 GT, and 1 unit of light boat size of 35 GT. The type of violations committed by the four ships was having no licenses, such as Fishery Business Permit Letter (Surat Izin Usaha Penangkapan or SIUP) and Fish Catching Permit Letter (Surat Izin Penangkapan Ikan or SIPI). The violation was declared 
as a crime (illegal fishing). Besides, it was also the violation against Indonesian Law No. 31 of 2004, Article 26, Paragraph 1, Jo Article 92, and Indonesian Law No. 45 of 2009, Article 27 Paragraph 2, Jo Article 93 Paragraph 2.

Moreover, the existence of a foreign ship is one of the problems in North Maluku, Indonesia. A survey that was conducted by researchers on fifty-one respondents showed that forty-seven respondents witnessed foreign ships that did fishing activities in the North Maluku water area. Meanwhile, the other four respondents did not know anything. From the data above, researchers concluded that the arrival of public ships in the North Maluku water area has become a common perception and a common issue. Although in the same respondents, the researchers found that forty-seven respondents acted against foreign ships, and four respondents did not know anything. In other words, the presence of foreign ships in the North Maluku waters area was a sign of weak sovereignty and weak law enforcement.

\section{RESEARCH METHOD}

This research was based on legal research, which conducted in a non-doctrinal qualitative approach. It is because, in this research, the law is not only conceptualized as a whole the principles and rules that regulate human life in society but also includes institutions and processes that actualize the validity of these rules in society.

\section{Research location}

This research was conducted in the waters area of North Maluku Province, North Halmahera District, Central Halmahera District, and South Halmahera District, Indonesia.

\section{RESULTS \& DISCUSSION}

As an area with great marine natural resources, Indonesia cannot be free from various threats. One of them is fishing crime or illegal fishing activity. Illegal fishing practices, which are internationally known as Illegal, Unreported, and Unregulated (IUU), are categorized in a phenomenon that threatens marine fish resources and their environment. Therefore, the Food and Agriculture Organization (FAO), as a world food agency, formulates a reference concerning the orderly, responsible, and sustainable management and development of fisheries that can be applied by countries in the world. 
The issue of illegal fishing firstly emerged when CCAMLR (Commission for Conservation of Atlantic Marine Living Resources) was held from $27^{\text {th }}$ October to $7^{\text {th }}$ November 1997. This forum was held to respond to the fishing issue done by non-CCAMLR member countries. This issue strengthened more into the Global realm by FAO, which assumed that fish theft could cause starvation threat because anyhow, sea fish became part of the staple food.

Illegal fishing is also regulated in the United Nations Convention on the Law of the Sea (UNCLOS), which has been signed on $10^{\text {th }}$ December 1982 by 117 countries, including Indonesia and two State units in Montego Bay, Jamaica.

The policy of the International Plan of Action to Prevent, Deter, and Eliminate IUU Fishing or IPOA-IUU Fishing in 2001 renewed the Code of Conduct for Responsible Fisheries in 1995 that was considered less responsive. IPOA-IUU is a global action plan that attempts to prevent environmental and endangered marine resources. Moreover, Indonesia is part of the global plan. ${ }^{7}$

\section{Customary Law Enforcement In North Maluku}

Agency of Ternate Sultanate customary community

According to Hi Ridwan Dero, an advisor for the Sultan of Ternate, institutionally, there is a customary community agency (Badan Masyarakat Adat or BMA) that is formed based on the command from Jo'ou Kolano (His Majesty) Sultan. The BMA of Ternate is an institution that is respected by the local community. Likewise, BMA, with other law enforcement agencies, such as police and other law enforcement agencies, is harmonious. The custom decision is valid as long as it does not oppose the 1945 State Constitution of the Republic of Indonesia.

BMA, according to the Adjudicator of Ternate District Court, Sugianur, has the authority to solve fish theft disputes as long as it does not oppose the 1945 State Constitution of the Republic of Indonesia and valid positive laws in Indonesia. Through that way, the local culture that is still acceptable in the indigenous community of North Maluku concerning procedures for fishing in the North Maluku sea must be perpetuated and maintained. Furthermore, it is acceptable as long as it does not oppose the positive laws in the Republic of Indonesia. This good relation is also seen between the BMA and the state Prosecutor, according to Samsuddin Ishak, Head of General Crimes Section in Ternate State Prosecutor.

\footnotetext{
${ }^{7}$ Sunyowati, Dina. (2013). Port State Measures dalam upaya pencegahan terhadap IUU Fishing di Indonesia, dalam Idris dkk, Peran Hukum dalam Pembangunan di Indonesia. Bandung: Rosdakarya.
} 
"Particularly, the Institution of State Prosecutors and Ternate Sultanate always have a good relationship. They coordinate with each other. If there is a dispute involving tradition, it would be solved by the Sultanate. However, if it involves general crime, the Sultanate would submit it to the authorities". The BMA Sultanate of Ternate is considered to have a good relationship between the citizens. It is proven by $98 \%$ of respondents who said that they have good relations with the Sultanate of Ternate, and only $1 \%$ of respondents said that he did not know, and $1 \%$ of respondents said that he was not harmonious with the Sultanate of Ternate.

The existence of BMA in the Sultanate of Ternate is guaranteed based on the recognition of the Constitution on the Customary Law, which more emphasized in Article 18B paragraph (2) that was stated as follows "State recognizes and respects community unity of customary law and their traditional rights as long as they are still alive and in line with the development of the community and the principles of the unitary state of the Republic of Indonesia, which are regulated in State Constitution of the Republic of Indonesia".

Decentralization spirit recognized community sovereignty as one of the motives in recognition of Customary Law. On the $27^{\text {th }}$ PAH I, BP MPR Meeting discussed Amendments of State Constitution of the Republic of Indonesia and Court Decision No. 35/PUU-X/2012 that examined Law of Indonesia No. 41 concerning Forestry on State Constitution of the Republic of Indonesia. In this decision, the Constitutional Court separated Customary Forest and State Forest that made the State must recognize the Customary Forest (Previously, in Article 1 Paragraph (6)).

The Local realm of Regional Regulation of Ternate City No. 13 of 2009 concerning the Protection of Customary and Cultural Rights of Customary Community in Sultanate of Ternate Article 7 stated that Regional Government recognized and protected Customary Institution of Ternate Sultanate. The Regional Regulation also protects rights against the customary community's land as long as it did not oppose the applicable law of Indonesia and regulations. The Land Rights as referred to the paragraph consists of:

a. Raki Kolano; Sultan's right to collect the harvest from a plot of land that is planted by the people, which the commodities are out of sago or staple food;

b. Raki Jo Ou; Right that is granted/controlled specifically or exclusively by Sultan's descendants (Dede);

c. Aha Kolano; Sultan's right for land that is planted with sago/staple food;

d. Aha Jou Ou; The right for Sultan's descendants to use the land by their wills; 
e. Kaha Soa; The Sultan's right to give a plot of land to be controlled by a certain clan;

f. Kaha Cocato; Right of private property that is owned by people; and,

g. Kaha Jorame; Right to open new land customarily with the Sultan's permission.

Meanwhile, in solving the dispute, Sultan is assisted by Bobato (minister). There are two types of Bobato. The first is Bobato who handles worldly matters (worldly Bobato). The second is Bobato who handles religious matters or sharia court (spiritual Bobato). This institution is led by a judge (Qadhi).

Worldly Bobato means the part that regulated matters of interests and worldly arrangements, including Ngaruha commission that is given a specific task as an executive institution, and Capita commission that is a government agency in the military field. Meanwhile, spiritual Bobato is the institution that regulates the implementation of Islamic matters. It comprises of (1) Jo Calm (Qadhi), (2) Islam communal prayer leader that consisted of Jiko Islam communal prayer leader, Javanese Islam communal prayer leader, Sangaji Islam communal prayer leader, Moti Islam communal prayer leader, and aristocratic Islam communal prayer leader, (3) Khatib (Islam preacher) that consisted of Jiko khatib, Javanese khatib, Sangaji khatib, aristocratic khatib, and written Jo Khatib, and (4) Modem. ${ }^{8}$ Traditional institute of Ternate Sultanate in 2018 had decided on three cases in the Kao bay waters area related to fish catching.

The presence of worldly Bobato and spiritual Bobato illustrates that customs, which are implemented in the community of Ternate sultanate and are still accomplished until now, are a combination of religious and cultural values as a form of local wisdom from Ternate people, which later it generates a tolerant Islamic culture. These values are cultural power that grows and develops in society. Then, it will be trusted and recognized as crucial elements that can strengthen social cohesion between citizens. ${ }^{9}$

In regulating life principles at sea, Ternate Customary Conference Agency complies with the policy of Haopo Fopa Mataipasi Moro Moro Matakubise, which is a theorem regulating life orders for the people to manage the sea. Hence, in addition to regulating legal procedures of the sea, it also regulates the procedures on how ships cross or lean on the harbor. From this principle, then, Ngase is applied, which is a kind of tax for a boat from the outside area that leaned.

\footnotetext{
${ }^{8}$ Mudafar. Syah. Tt. Lingkungan Hidup Adat Ternate. Ternate Maluku Utara

${ }^{9}$ Liliwere. A. (2003). Dasar-Dasar Komunikasi Antar Budaya. Yogyakarta: Pustaka Pelajar.
} 


\section{Deliberation values in the BMA of Ternate Sultanate}

One of the problems in law enforcement from positive law is the lack of justice meaning and the non-opening from law enforcers against values in society. Lastuti Abubakar said that customary law institutions are currently alternative legal institutions, which are essential to be used as a basis or source informing national law. ${ }^{10}$

This strategic role is crucial because customary law institutions have a substantive approach to law enforcement. A functional approach is formed in deliberation form, which is a fundamental communication pattern of various indigenous people in resolving every dispute. In deliberations, the final decision is determined together by consensus. Thus, each party to the disagreement becomes equally unaffected and receives justice as expected.

Deliberation becomes the main characteristic in solving customary violations in the BMA of Ternate. Therefore, those who violate customary law are confronted with the BMA to agree on what type of violation is and how the settlement is. After being approved by the Sultan of Ternate, the customary verdict will be applied. However, the customary fisheries and maritime laws of the Sultanate of Ternate is not written, but it is in verbal. It is known as "Dola Bololo" or messages that contain fisheries and marine laws, which is stated by Jo'ou Kolano Sultan of Ternate. The messages are applied by Institution of Indigenous Peoples in the Sultanate of Ternate, Indonesia.

Dola Bololo (Dorobololo) is an expression that is consisted of two stanzas, which are someone's statement of feelings and opinions in satire and imagery side. It means a characteristic of someone's insight into society to convey his feelings and opinions through proverbs toward someone or his friend. Hence, his friend can understand and respond to the intentions and will not feel offended by the satirical language used. Communicating by using Dola Balolo language is more memorable, having polite language, indirect insinuations, and it is easily understood what and how someone's intentions and opinions are. Dola Balolo is conveyed mostly through conversations between two or more people, wherever the place and whenever the time if they are meeting, especially in giving advice and lectures. The example of Dola Balolo (Dorobololo) is as follows:

Fala to mataka-taka Dego-dego to ruraka

\footnotetext{
${ }^{10}$ Abubakar, Lastuti (2013). Revitalisasi hukum adat sebagai sumber hukum dalam membangun sistem hukum Indonesia. Jurnal Dimaika Hukum, Vol.13 No,2.
} 
The house that I am not ordinary makes me embarrassed to occupy the chair

Ha ufo ma taipasi Moro-moro fo maku ise

Fishing in a different place, the cheerful sound is heard one another

Sagadi no ngolo-ngolo Bara lou maginyau

Scattering in a unanimous effort with ancestral advice

Dara to lefo mapila Soro gudu to nonako

I cut pigeons' wings. if they fly far away, I will recognize them

Loleo igo ma ake Kore koa yo i dahe

Flooded like water in a coconut. Can wind penetrate it

Further, there is also Dalil Moro in old literary poetry and its proverb. It expresses a parable in theorem as an example to be imitated that is a legacy from ancestors who have possessed and have been lived. Thus, it should be obeyed. The content and meaning from Dalil Moro are about the nature of human life, which each individual in society is required to be able to place themselves in society and be able to create an atmosphere of diversity that can create bonds between fellow humans in family relations to a bigger group or society. However, it is never to be in an uncertain situation that leads to an unclear direction. Conveying Moro Theorem is usually through conversation, especially among parents, but it is now rarely done.

The deliberation concept is implemented based on the customary principle of "ale rasa beta rasa" through the Pela Gandong culture (sibling). Pela means brotherhood between one person and another and between others. There are three types of Pela. They are Pela Karas (Hard), Pela Gandong (sibling) or Bongso (Youngest), and Pela Tampa Siri (Place of Betel leaf). Pela Karas is a vow that is pledged between two areas (villages) or more due to a very crucial event. It generally relates to warfare, such as sacrifice, the end of the uncertain war (no one wins or defeats a war), or there is special help from one country to another country. Pela Gandong or Bongso is based on blood ties or descendants to maintain relations between family relatives who are in different countries or islands. Meanwhile, Pela Tampa Siri is held after an event that is not very vital, such as reconciling after a small incident or when one country has served to another country. This type of pela is also usually determined to promote trading relations. ${ }^{11}$

Also, there are customary values that uphold fraternity, which are:

${ }^{11}$ I. H. Wenno. (2011). Budaya “Ale Rasa Beta Rasa” Sebagai Kearifan Budaya Lokal Maluku Dalam Pembentukan Karakter Bangsa, Cakrawala Pendidikan, Special Edition of Dies Natalis UNY. 
1) Hatu molo upai miki (teaching people to be fair and be considerate in relationships).

2) Hawa-hatopo luna nanaho waymaynyi ehe ula maa' tune (life may not be selfish and must pay more attention to the others around).

3) Ihela mansiya rupa ihela nuja (people may not act arbitrarily towards others, especially toward weak people).

4) Kasturi joro jurami madukopoga caga luara (a person must develop a considerate attitude).

5) Limuk limor kweunum kweanam (either in difficulty or in pleasure, we should help one another).

6) Potong di kuku rasa didaging (insulting someone in a community, it is the same as insulting all members of a community).

7) Biar barutang tambah bagade tar mau ilang kecuali (although in a difficult situation, we should still help each other).

8) Sagu salempang pata dua (even though having a difficult life, we have to help each other).

9) Tidor satu bantal makang satu piring (there is a union bond).

Those traditional values become a basic framework in making legal decisions for solving customary cases in the Institution of Indigenous Peoples in Ternate Sultanate. Those values indicate the necessity of taking sides with residents or fishermen as a form of brotherhood and conversely. It represses the foreign fishermen.

\section{The Implementation of Customary Criminal Sanctions by Customary Deliberation Agency}

In the fishery context of the Sultanate maritime law that is acceptable in Maluku, according to Ridwan Dero in the Sultanate law, fish-catching is only prohibited in places where other people are doing fish catching in the same place. According to Ofa Hidayat Syah, Sultanate acts as a Customary Deliberation Agency that has right in three territorial waters. They are Ngolosahe Right, Ngolongido Right, and Ngololamo Right.

As we know, Ngololamo is a deep-sea in which the sun cannot shine its bottom. Meanwhile, Ngolongido right is still in the ocean that is still visible in the bottom. Ngolosahe right is coast in the coastal area. From the territorial division of this sultan's authority law, other rules develop more, such as the law in regulating fish theft, the ship parking in the Ternate 
District area, and the rights to cross Ternate sultanate territory for lasing ships. ${ }^{12}$ According to Ofa, activities in the Ternate sultanate waters such as crossing the territory or other activities must be conducted by Syahbandar's permission from the port that is owned by the Ternate kingdom. If there is no permission from the Syahbandar, it means violating the customary law of the Ternate kingdom and must be submitted to the authorized legal entity, which is Sangadji law and the common law, for being adjudicated and sanctioned.

Every violation in the Ternate waters area, firstly, will be conducted court trial of a breach by Syahbandar, which are attended by Panira, Capita, Mahimo, and Ser ah. After this decision is settled, it will be submitted to Ngaruha Commission. It will be decided in a binding manner by Sangadji law and social law that is Attorney General (Interview with Ofa Hidayat Syah, 2019). As a legal institution, Sangadji law and social law have double functions. They are as a prosecutor and, at the same time, Sangadji and social law, also have the authority to examine, adjudicate, and decide a case.

The decisions of Sangadji and Social Laws are based on bobasah sora sai ideology. In traditional values, there are about eight values, 1) catorang, 2) great customs, 3) galif salakudik; 4) serese duniru, 5) cing secing are, 6) cara sengale, 7) bobaso sara sai, 8) Loaso benar. These customary decisions must be considered more based on loaso benar, which is direct and right. It also must be considered based on taste, bobasoh sara sai. Thus, every decision from either Sangadji Law or Social Law may not be arbitrary. ${ }^{13}$

According to sanction in Sultanate that has been determined by the local customary head to fish theft perpetrators in waters area, it can be in the form of (1) warning; (2) monetary charges following the agreement from local indigenous people; and (3) boats (pajeko in Ternate language) or fishing motorboats are confiscated by the sultanate to be used by the community through profit sharing.

Furthermore, this research showed that thirty-nine respondents agreed with the Sultanate rules, which stated that ships from foreign countries should be confiscated and used for local fishers. Meanwhile, eight respondents did not agree with the customary laws, and four respondents had other suggestions. M. Alief Zidane stated that ships that are confiscated could be privately owned by individuals, not be leased through the Sultanate.

\footnotetext{
12 Interview with Ofa Hidayat Syah, 2019

13 Ibid
} 


\section{CONCLUSION}

Substantially, the norm that was applied is the Sasi norm of a rule, such as recommendations and prohibitions in the production process. The sanction that is given to fish theft perpetrators in waters area that has been determined by the customary local head is in the form of (1) warning; (2) monetary charges following the agreement from local indigenous people; and (3) boats (pajeko in Ternate language) or fishing motorboats are confiscated by the sultanate to be used by the community through profit sharing. Culturally, legal norms of customary law norms are still recognized by Ternate people although it is limited in a certain budget. North Maluku recognizes Sasi Customs, which is a customary regulation that limits people to catch fish or take other resources in certain types and a particular period. Thus, the ecological balance is still maintained.

Weak Law Enforcement and susceptible Corruption, collusion, and nepotism indicated that law enforcer does not have a political will and a broad view concerning ecology and natural balance. The corruptive attitude is a part of weak spiritual awareness. Hence, it needs an approach that accommodated religious values and has God-oriented (Transcendental). Transcendental law enforcement concept is substantially in line with the values in Segulaha customs, which has been applied since a long time ago in North Maluku. In Segulaha customary law, there is a traditional element in a person who has the same soul with transcendental values by positioning revelation as the source of law. Finally, from the culture, it is reflected in dorobololo and Moro Theorem. Moreover, Ternate customary law still has support. It generates good relationships with the community while the part of the community's desire is achieving prosperity together.

\section{REFERENCES}

\section{Book}

Abubakar, Lastuti (2013). Revitalisasi hukum adat sebagai sumber hukum dalam membangun sistem hukum Indonesia. Jurnal Dimaika Hukum, Vol.13 No,2.

Buntoro, Kresno. (2013). Kegiatan Militer Di Zee Dan Pelaksanaan Hot Pursuitdi Indonesia. Jurnal Opinio Juris, Vol. 12.

I. H. Wenno. (2011). Budaya "Ale Rasa Beta Rasa" Sebagai Kearifan Budaya Lokal Maluku Dalam Pembentukan Karakter Bangsa, Cakrawala Pendidikan, Special Edition of Dies Natalis UNY. 
Kardono, Priyadi (Ed). (2015). Paradigma Geomaritim; Strategi Mewujudkan Indonesia Sebagai Poros Maritim Dunia dalam Perspektif Geografi. Diterbitkan oleh Badan Informasi Geospasial (BIG) didukung oleh Ikatan Geograf indonesia (IGI)

Lapian, AB. (2015). Orang Laut-Bajak Laut-Raja Laut - Sejarah Kawasan Laut Sulawesi Abad XIX. Depok: Komunitas Bambu.

Lewerissa, Yanti Amelia. (2010). Praktek Illegal Fishing di Perairan Maluku sebagai Bentuk Kejahatan Ekonomi. Jurnal Sasi, Vol.16. No.3.

Liliwere. A. (2003). Dasar-Dasar Komunikasi Antar Budaya. Yogyakarta: Pustaka Pelajar.

Mudafar. Syah. Tt. Lingkungan Hidup Adat Ternate. Ternate Maluku Utara

Naim, Armain. (2010). Pengawasan Sumberdaya Perikanan dalam Penanganan Illegal Fishing di Perairan Provinsi Maluku Utara, Jurnal Ilmiah agribisnis dan Perikanan (agrikan UMMU-Ternate) Volume 3 Edisi 2.

Sunyowati, Dina. (2013). Peran Hukum dalam Pembangunan di Indonesia. Bandung: Rosdakarya

Sunyowati, Dina. (2013). Port State Measures dalam upaya pencegahan terhadap IUU Fishing di Indonesia, dalam Idris dkk, Peran Hukum dalam Pembangunan di Indonesia. Bandung: Rosdakarya.

\section{Indonesian Constitution and Regulation}

Undang-Undang Nomor 45 tahun 2009 tentang Perikanan

Undang-Undang Nomor 8 Tahun 1981 tentang Kitab Undang-Undang Acara Pidana

Undang-Undang Nomor 5 Tahun 1983 tentang Zona Ekonomi Eksklusif Indonesia;

Undang-Undang Nomor 6 Tahun 1996 tentang Perairan Indonesia

Undang-Undang Nomor 2 Tahun 2002 tentang Kepolisian

Peraturan Pemerintah No 50 Tahun 2010 tentang Peraturan Pelaksana Kitab Undang-Undang Hukum Acara Pidana

Peraturan Pemerintah No 17 Tahun 2012 tentang Kepolisian

Putusan Mahkamah Konstitusi Nomor : 28/PUU-V-2007 Tentang Pengujian Undang-Undang Nomor 16 tahun 2004 tentang Kejaksaan RI Terhadap Undang-Undang Dasar 1945 (Kewenangan Penyidik)

\section{Interview}

Wawancara dengan Andi, Anggota Kejaksaan Negeri Maluku Utara, 10 Februari 2018, pukul 10.30 WIT

Wawancara dengan Arman Naim, minggu pertama ramadhan 12 Pukul 12.30

Wawancara dengan Samsudi Ishak / Noke Nama Jaksa / Kasipidum pada Pukul 10:00, perwira yang dimaksud oleh Noke berinisial AJ.

Wawancara Sugianur, SH, Hakim pada Pengadilan Negeri Ternate pada pukul 10:00.

Wawancara dengan Om Ade, Nelayan di Perairan Maluku Utara, 16 Januari 2018, Pukul 09.00 WIT

Wawancara Jainudin dinas perikanan pulau morotai, 16 Mei 2019 Pukul 10.00

Wawancara dengan Daud Gobasa, warga desa Posi-Posi, 18 Januari 2018, pukul 17.00 WIT 